\title{
Editing the genome of Aphanomyces invadans using CRISPR/Cas9
}

\author{
Muhammad Majeed, Hatem Soliman, Gokhlesh Kumar, Mansour El-Matbouli and Mona Saleh
}

\begin{abstract}
Background: The clustered regularly interspaced short palindromic repeats (CRISPR)/CRISPR-associated protein 9 (Cas9) system is increasingly being used for genome editing experiments. It is a system to add, delete and/or replace parts of a gene in situ in a time- and cost-efficient manner. The genome of many organisms has been edited using this system. We tested the CRISPR/Cas9 system in Aphanomyces invadans, an oomycete, which is the causative agent of epizootic ulcerative syndrome (EUS) in many fish species. Extracellular proteases produced by this oomycete are believed to play a role in EUS virulence.

Methods: We designed three single guide-RNAs (gRNA) to target $A$. invadans serine protease gene. These gRNAs were individually combined with the Cas9 to form ribo-nucleo-protein (RNP) complex. A. invadans protoplasts were then transfected with RNP complexes. After the transfection, the target gene was amplified and subjected to sequencing. Zoospores of $A$. invadans were also transfected with the RNP complex. Three groups of dwarf gourami (Trichogaster lalius) were then experimentally inoculated with (i) non-treated A. invadans zoospores; (ii) RNP-treated A. invadans zoospores; and (iii) autoclaved pond water as negative control, to investigate the effect of edited serine protease gene on the virulence of $A$. invadans in vivo.

Results: Fluorescence microscopy showed sub-cellular localization of RNP complex in A. invadans protoplasts and zoospores. Sequencing results from the protoplast DNA revealed a point mutation in the target gene. A matching mutation was also detected in zoospores after similar treatment with the same RNP complex. In vivo results showed that the CRISPR/Cas9-treated A. invadans zoospores did not produce EUS clinical signs in the fish. These results were then confirmed by histopathological staining of the muscle sections using Gomori's methenamine silver nitrate and hematoxylin and eosin stains.

Conclusions: Results obtained in this study indicate that the RNP complex caused effective mutation in the target gene. This hindered the production of serine protease, which ultimately impeded the manifestation of EUS in the fish. Our methods thus establish a promising approach for functional genomics studies in A. invadans and provide novel avenues to develop effective strategies to control this pathogen.
\end{abstract}

Keywords: CRISPR/Cas9, Dwarf gourami, Epizootic ulcerative syndrome, Oomycetes, Point mutation, Proteases, Virulence

\section{Background}

Oomycetes are a group of parasites that are widespread and have the ability to invade a wide range of hosts [1]. Three oomycete genera, namely Achlya, Aphanomyces and Saprolegnia, have been described as the most devastating pathogens of aquatic organisms [2-4]. Aphanomyces alone contains approximately 35-40 species,

\footnotetext{
* Correspondence: Mansour.El-Matbouli@vetmeduni.ac.at Clinical Division of Fish Medicine, University of Veterinary Medicine, Vienna,
} Austria

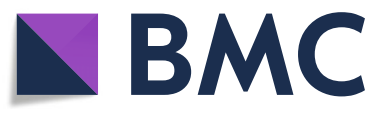

(c) The Author(s). 2018 Open Access This article is distributed under the terms of the Creative Commons Attribution 4.0 International License (http://creativecommons.org/licenses/by/4.0/), which permits unrestricted use, distribution, and reproduction in any medium, provided you give appropriate credit to the original author(s) and the source, provide a link to the Creative Commons license, and indicate if changes were made. The Creative Commons Public Domain Dedication waiver (http://creativecommons.org/publicdomain/zero/1.0/) applies to the data made available in this article, unless otherwise stated.

some of which are specialized pathogens of plants and animals while others are saprotrophic or opportunistic pathogens growing on animals and plant debris $[5,6]$.

The species Aphanomyces invadans has been identified as the primary cause for epizootic ulcerative syndrome (EUS), which is an important seasonal condition implicated in mass-mortalities of cultured and wild fish in many countries $[7,8]$. As soon as the free-swimming zoospore, the infective stage of $A$. invadans, finds a fish host, it germinates into vegetative non-septate hyphae, 
which invade the fish skin and muscular tissue and may also reach the internal organs $[9,10]$. Then, the primary zoospores develop in the sporangium in fish tissues and are released at its tip where they form a spore cluster [11]. The primary spores transform into motile, biflagellate secondary zoospores. The life-cycle is completed once they find new fish to invade [12].

In addition to the distinctive mycotic granulomas in internal tissues, infected fish display distinct dermal lesions appearing as red spots, blackish burn-like marks or deeper ulcers with red centers and white rims [7, 1315]. More than 125 fish species have been reported to be affected by $A$. invadans [16]. Because of its epizootic nature, broad fish host range and potential impact on cultured and wild fisheries, EUS is officially recognized as a reportable disease by the World Organization for Animal Health [17].

Although a large amount of data on the gross and microscopic clinical lesions of EUS and the involvement of different pathogens during the course of the disease already exist $[9,16-18]$, there still is a paucity of information regarding pathogenicity, host-parasite interactions, molecular mechanisms of the disease and the functional genomics of $A$. invadans. Similar to many pathogenic microorganisms, proteases secreted by $A$. invadans are key in the pathogenesis of EUS [19]. Different extracellular proteins, most of which are proteases, secreted by $A$. invadans, have recently been identified and at least one of these proteases (serine protease belonging to peptidase_S8 domain) is believed to be involved in the degradation of the fish immunoglobulin $\mathrm{M}$ [20]. Serine proteases have long been thought of as the virulence factors in many of the true bacteria and fungi [21]. A serine protease secreted by the fish-pathogenic oomycete $S$. parasitica has been reported as able to degrade the fish IgM [22]. Accordingly, these genes were our target for gene editing to investigate their role in $A$. invadans pathogenesis.

Genome editing is a group of technologies that allow the scientists to make precise changes by adding, removing and/or altering genetic material at particular locations in the genomes of eukaryotic cells [23-25]. In addition to the currently used techniques for genome editing, such as zinc finger nucleases (ZFN) and transcription activator-like effector nucleases (TALEN), a relatively recent technique known as clustered regularly interspaced short palindromic repeats (CRISPR)/CRISPR-associated protein (CRISPR/Cas) system is already revolutionizing our ability to interrogate gene functions and can potentially be used clinically to correct or introduce genetic mutations [24, 26-28].

According to the current classification of CRISPR-cas loci the CRISPR/Cas system has been grouped into six distinct types (I-VI). Each type employs a unique set of Cas proteins along with CRISPR RNA (crRNA) for CRISPR interference [29]. The Type II CRISPR system employs a single DNA endonuclease, Cas9, to recognize double-stranded DNA (dsDNA) substrates and cleave each strand with a distinct nuclease domain [30-33]. The use of CRISPR/Cas9 as an RNA-programmable DNA targeting and editing platform is simplified by a synthetic single guide RNA (gRNA) mimicking the natural dual trans-activating CRISPR RNA (tracrRNA)-crRNA structure [34].

Because of its simplicity, specificity and versatility, the CRISPR/Cas system has recently emerged as a powerful tool for genome engineering in various species [35-38] including fungi [39-41] and bacteria [42-45]. In oomycetes, CRISPR/Cas9-mediated gene disruption and gene replacement were performed to test the function of specific genes in Phytophthora sojae, the causative agent of stem and root rot of soybeans [46-48].

The aim of the present study was to use CRISPR/Cas9 system to edit the genome of $A$. invadans by targeting the serine protease gene in vitro and study the effect of this genome editing on the virulence and pathogenicity of the A. invadans in vivo.

\section{Methods}

Aphanomyces invadans growth and zoospore production Aphanomyces invadans strain 9701 was used in this study. It is routinely grown on glucose-peptone-yeast (GPY) agar and maintained on glucose-peptone (GP) agar at $25^{\circ} \mathrm{C}$ according to Lilley et al. [9]. For zoospore production, agar plugs $(4 \mathrm{~mm})$ were aseptically transferred from stock cultures to GPY agar and grown for $4-5$ days at $25^{\circ} \mathrm{C}$. A piece of agar containing hyphae from the growing edge of a colony was then aseptically transferred to GP broth supplemented with oxolinic acid $(100 \mu \mathrm{g} / \mathrm{ml})$ and incubated at $25{ }^{\circ} \mathrm{C}$ for $3-4$ days. The resulting mycelial wads were then aseptically removed from the broth, rinsed four times with sterile distilled water and transferred into Petri dishes containing $20 \mathrm{ml}$ filtered autoclaved pond water (APW) (one part filtered river water combined with one part distilled water) for $24 \mathrm{~h}$. The production of secondary zoospores was microscopically monitored. The produced zoospores were counted using a hemocytometer.

\section{Design of gRNAs and the formation of ribo-nucleo- protein (RNP) complexes}

The Eukaryotic Pathogen CRISPR Guide RNA Design Tool (EuPaGDT) [49] was used to design the gRNAs for serine type protease of $A$. invadans (gene ID: 20088162). Secondary structures were checked using RNAstructure, a web server tool for RNA secondary structure prediction [50], while off-targets were checked using FungiDB as per Fang \& Tyler [48]. Sequences of chosen gRNAs were submitted to Integrated DNA Technologies, Skokie, USA, for in vitro synthesis of crRNA. tracrRNA labeled with a 
fluorescent dye $\mathrm{ATTO}^{\mathrm{TM}} 550$ and Alt- $\mathrm{R}^{\mathrm{TM}}$ (Streptococcus pyogenes) S.p. Cas9 nuclease 3NLS were purchased from Integrated DNA Technologies. crRNA and tracrRNA were separately resuspended in nuclease-free duplex buffer (Integrated DNA Technologies) to produce $100 \mu \mathrm{M}$ stock solution. Subsequently, $30 \mu \mathrm{l}$ from each were mixed and annealed at $95{ }^{\circ} \mathrm{C}$, according to manufacturer's instructions, and then cooled at room temperature (RT). Each gRNA $(1 \mu \mathrm{M})$ was combined with Cas9 $(1 \mu \mathrm{M})$ in Opti-MEM media supplemented with GlutaMax (Thermo Fisher, Vienna, Austria) to form the RNP complexes. After incubation of the mixture for $5 \mathrm{~min}$ at RT, the complex was ready for transfection.

\section{PCR primers}

Three PCR primer sets (product sizes 211, 214 and 209 bp) corresponding to each gRNA were designed (Table 1) based on the $A$. invadans target gene (GenBank: XM_008877667) to amplify the target fragment and observe the genomic DNA mutation caused by Cas9 and gRNAs in the target gene via sequencing of the amplified products. Possible homology of the selected oligonucleotides was excluded using BLASTn analysis.

\section{Protoplast isolation}

Aphanomyces invadans protoplasts were isolated following the method described by Fang et al. [47] with minor modifications. Briefly, A. invadans mycelia were peeled off of the GPY plates (or the plug of germinated zoospores was isolated from the broth), rinsed first in water and then in 0.8 M mannitol (Sigma-Aldrich, Vienna, Austria) for $10 \mathrm{~min}$ each. Plasmolysis was carried out using $0.8 \mathrm{M}$ mannitol for $20 \mathrm{~min}$. Subsequently, the digestion process was completed using $20 \mathrm{ml}$ enzyme solution [0.4 M mannitol, $20 \mathrm{mM} \mathrm{KCl}$, $20 \mathrm{mM}$ 2-(N-morpholino) ethanesulfonic acid (MES) (pH 5.7), $10 \mathrm{mM} \mathrm{CaCl} 2,0.5 \%$ lysing enzymes from Trichoderma harzianum and 0.5\% CELLULYSIN ${ }^{\odot}$ Cellulase (Sigma-Aldrich)] for $45 \mathrm{~min}$ on a $50 \times \mathrm{rpm}$ shaker. Digestion efficiency for the release of protoplasts in the solution was checked under a light microscope (Olympus BX53, Tokyo, Japan). The digestion product was then filtered through $70 \mu \mathrm{m}$ Corning ${ }^{\oplus}$ cell strainers (Sigma-Aldrich) to remove mycelial debris. The flow-through was collected and centrifuged at $1200 \times g$ for $2 \mathrm{~min}$. The supernatant was then discarded and the pellet washed by slowly adding up to $5 \mathrm{ml}$ of W5 solution $\left(5 \mathrm{mM} \mathrm{KCl}, 125 \mathrm{mM} \mathrm{CaCl}_{2}, 154 \mathrm{mM} \mathrm{NaCl}\right.$ and 177 $\mathrm{mM}$ glucose). Excess W5 solution was discarded after spinning the tube at $1200 \times g$ for $2 \mathrm{~min}$. W5 solution $(2 \mathrm{ml})$ was added and protoplasts were placed on ice for $20 \mathrm{~min}$. Protoplasts were spun again at RT and excess W5 solution was removed. Protoplasts were then resuspended by gently adding $2 \mathrm{ml}$ of MMG solution [0.4 M mannitol, $15 \mathrm{mM} \mathrm{MgCl}_{2}$ and $4 \mathrm{mM} \mathrm{MES} \mathrm{(pH} \mathrm{5.7)]} \mathrm{at} \mathrm{RT} \mathrm{for} 10 \mathrm{~min}$. The protoplasts were counted and optimized to $10^{5}$ per $\mathrm{ml}$.

\section{Transfection of $A$. invadans protoplasts}

Polyethylene glycol (PEG)-mediated RNP delivery into the protoplasts was carried out following the protocol described by Malnoy et al. [51] with minor modifications. Briefly, $200 \mu \mathrm{l}$ of resuspended $A$. invadans protoplasts (20,000 protoplasts) were mixed with $12 \mu \mathrm{l}$ RNP and incubated at RT for $10 \mathrm{~min}$. Another $200 \mu \mathrm{l}$ protoplast suspension was mixed with $12 \mu \mathrm{l}$ opti-MEM medium and incubated for $10 \mathrm{~min}$ at RT to be used as a control. An equal volume of PEG 4000 (Sigma-Aldrich) was added, gently mixed and incubated at RT for a further $20 \mathrm{~min}$. W5 solution $(400 \mu \mathrm{l})$ was then added, mixed and kept at RT for $10 \mathrm{~min}$, followed by the addition of $800 \mu \mathrm{l}$ W5 solution. After another $10 \mathrm{~min}$ of incubation at $\mathrm{RT}$, the protoplasts were centrifuged at $50 \times g$ for $5 \mathrm{~min}$. The supernatant was discarded and the pellet was washed with $500 \mu \mathrm{l}$ W5 solution and incubated at RT overnight. To observe the efficient delivery of RNP into the protoplasts, $15 \mu \mathrm{l}$ of each transformation mixture including control was sampled and examined by fluorescence microscopy. Regeneration media (double strength GPY broth) was then added and the mixture was divided into two parts; one part was used for DNA extraction and the other incubated for 3-4 days at $25{ }^{\circ} \mathrm{C}$ to ensure that the RNP did not affect the viability of the protoplasts.

\section{Transfection of $A$. invadans zoospores}

Aphanomyces invadans zoospores (4000 zoospores in 400 $\mu$ l suspension) were transfected by adding $24 \mu \mathrm{l}$ of RNPs and incubated at RT for $60 \mathrm{~min}$. Non-treated zoospores were used as control. Both treated and non-treated zoospores $(200 \mu \mathrm{l})$ were then subjected to DNA extraction, PCR and sequencing to observe the mutation. The other $200 \mu \mathrm{l}$ of zoospores were added to GYP medium and incubated at $25{ }^{\circ} \mathrm{C}$ for $4-5$ days to demonstrate the effect of RNP complex on the viability and growth of the treated zoospores.

\section{Detection of targeted mutation}

DNA from RNP-treated and non-treated $A$. invadans protoplasts and zoospores were isolated using Qiagen DNeasy Blood \& Tissue Kit (Qiagen, Vienna, Austria) according to the manufacturer's instructions. To exclude the possibility of mutations caused during PCR amplification, Platinum SuperFi Green PCR Master Mix (Invitrogen, Vienna, Austria) was used in all PCR reactions. The amplification reaction mixture consisted of $12.5 \mu \mathrm{l}$ Platinum SuperFi Green PCR Master Mix, 15 pmol of each sense and antisense primers, $2.5 \mu \mathrm{l}$ DNA template and PCR grade water to a final volume of $25 \mu \mathrm{l}$. The reaction mixture was subjected to 35 amplification cycles comprising: denaturing at $98{ }^{\circ} \mathrm{C}$ for $10 \mathrm{~s}$, annealing at $57^{\circ} \mathrm{C}$ for $10 \mathrm{~s}$ and extension at $72{ }^{\circ} \mathrm{C}$ for $30 \mathrm{~s}$. The amplification cycles were preceded by 
an initial denaturing step of $98{ }^{\circ} \mathrm{C}$ for $30 \mathrm{~s}$ followed by an extended elongation step of $72{ }^{\circ} \mathrm{C}$ for $5 \mathrm{~min}$. Amplified products were analyzed on $1.5 \%$ agarose gel.

For sequencing, PCR products were purified using MinElute gel extraction kit (Qiagen) as per the manufacturer's instructions. The purified products were either directly sequenced or incubated with Taq polymerase buffer, dATP and Taq polymerase enzyme at $72{ }^{\circ} \mathrm{C}$ for 20 min to add 3' adenines to the blunt-end fragments for TA cloning. For TA cloning, PCR products were cloned into the $\mathrm{pCR}^{\circ} 4-\mathrm{TOPO}^{\circ}$ vector using $\mathrm{TOPO}$ TA cloning ${ }^{\circ}$ kit (Invitrogen) according to the manufacturer's instructions. The purified PCR products and recombinant plasmids were subjected to sequencing in a commercial sequencing laboratory (LGC Genomics, Berlin, Germany). Sequences were subjected to BLASTn analysis for sequence identity and then compared with the A. invadans target gene (GenBank: XM_008877667) to detect the mutation.

\section{In vivo investigation of the effect of CRISPR/Cas9-treated}

\section{A. invadans zoospores on dwarf gourami fish}

Dwarf gourami (Trichogaster lalius) were purchased from a local pet shop in Austria. Five random fish were taken for bacteriological and parasitological analyses to rule out the possibility of other infections prior to the in vivo experiment. Furthermore, muscle samples were taken from these 5 fish for PCR to rule out the possibility of prior infection with $A$. invadans according to Vandersea et al. [52]. Fish $(n=180$, mean total length $4.5 \pm$ $0.5 \mathrm{~cm}$ and mean weight $5 \pm 0.5 \mathrm{~g}$ ) were kept in aquaria containing de-chlorinated water and equipped with air stones and aquarium heaters to provide aeration and maintain the temperature at $24 \pm 1{ }^{\circ} \mathrm{C}$. Water was changed $(25 \%)$ weekly to maintain water quality. After 3 weeks of acclimatization, fish were divided into three groups. Each group had three replicates and each replicate contained 20 fish. The fish were anaesthetized using MS-222 (Sigma-Aldrich) $150 \mathrm{ppm}$ prior to zoospore injection. After transfection of $A$. invadans' zoospores with RNP complex for $60 \mathrm{~min}$, each fish in the RNP-2-treated group was intramuscularly injected with $0.1 \mathrm{ml}$ of 10,000 zoospores/ml spore suspension (1000 zoospores/ fish). Similarly, in the positive control group, each fish received $0.1 \mathrm{ml}$ of 10,000 zoospores/ml non-treated $A$. invadans zoospores intramuscularly. The negative control group was inoculated with an equal volume of APW. All fish were monitored daily for characteristic EUS clinical signs for 30 days. Fish with clinical signs were collected as appropriate. Similarly, fish were sampled from both RNP-2-treated and negative control groups. Collected fish were euthanized and subjected to histological and PCR examinations for confirmation of $A$. invadans. Skin and muscle tissues were excised from lesion area and divided into two parts. One part was subjected to DNA extraction and the second part was fixed in $10 \%$ phosphate-buffered formalin for histology.

\section{Histopathology}

Tissue samples were processed through an automatic tissue processor and embedded in paraffin. The paraffin blocks were then sectioned at $4 \mu \mathrm{m}$ thickness and stained with Gomori's methenamine silvernitrate (GMS) and hematoxylin and eosin (H\&E) stains [53]. Stained sections were viewed under a light microscope (Olympus BX53). Photomicrographs were taken with a camera (Olympus DP73) attached to the microscope and processed using CellSens Standard software of Olympus.

\section{Results}

\section{Design of $A$. invadans specific gRNAs}

Targeting a serine type protease of A. invadans [20], gRNA candidates were suggested by the gRNA design tool and further filtered for secondary structure and off-targets. Based on their high total and efficiency scores and zero off-target hits, three gRNA candidates were selected (Table 2), synthesized and used for the formation of 3 separate RNP complexes.

\section{Transfection of protoplasts and zoospores with RNP complexes}

After the formation of RNP complexes, they were used separately to transfect the isolated $A$. invadans protoplasts. Examination of the successful transfection by fluorescence microscope revealed clear signals within the protoplasts (Fig. 1) and no signal in non-treated control samples. After regeneration of the RNP-treated protoplasts in GPY medium for 3-4 days, the protoplasts treated with the RNP-2 complex demonstrated a different growth pattern than those treated with RNP-1, RNP-3 and the non-treated control protoplasts (Fig. 2). Correspondingly, the RNP-treated zoospores demonstrated slow growth behavior in GYP medium compared with the non-treated controls.

\section{Detection of targeted mutation}

The expected $A$. invadans DNA fragments were successfully amplified from RNP-treated and non-treated protoplasts and zoospores (Fig. 3). Sequencing results revealed a mutation located at the 5 th $n$ trom the PAM site in sequences of the targeted fragments amplified from protoplasts and zoospores treated with RNP-2 complex (Fig. 4). Comparatively, no mutation was detected in the sequences of protoplasts and zoospores treated either with RNP-1 or RNP-3. 
Table 1 PCR primers designed for each guide RNA. Three PCR primer sets corresponding to each gRNA were designed based on the A. invadans target gene (GenBank: XM_008877667) to detect the genomic DNA mutation, caused by CRISPR/Cas9

\begin{tabular}{lllll}
\hline & Name & Position & Expected product size $(\mathrm{bp})$ & Sequence $\left(5^{\prime}-3^{\prime}\right)$ \\
\hline Primer set 1 & AiCr1F & $35-54$ & 211 & GACTCCGACCTTGACGATGC \\
& AiCr1R & $227-246$ & & AAAGAGGAATGAGGCGGAGG \\
Primer set 2 & AiCr2F & $884-904$ & 214 & CCCACACCATGGGAACGATTG \\
& AiCr2R & $1080-1098$ & & TTGAGACGAGCCCCACGAG \\
Primer set 3 & AiCr3R & $1572-1591$ & 209 & GTTCGGCCGTATTAACGCCA \\
& AiCr3F & $1763-1781$ & & CTTGGTACATGGCTGCCCA \\
\hline
\end{tabular}

\section{In vivo experiments}

At 3 days post-infection (dpi), fish within the positive control group inoculated with non-treated zoospores demonstrated swelling, reddening of skin and loss of scales; red ulceration underlying musculature was observed at $5 \mathrm{dpi}$. The ulceration further developed into deep ulceration with cotton-like threads at $7 \mathrm{dpi}$ (Fig. 5a, b). Swimming behavior of the fish was affected and the fish showed weakness at $10 \mathrm{dpi}$. The presence of $A$. invadans DNA in the sampled fish tissues was confirmed by PCR and sequencing. Fish inoculated with the RNP-2-treated zoospores (Fig. 5c) and fish within the negative control group inoculated with APW (Fig. 5d) did not show any clinical signs during the 30 days of the experiment. PCR did not amplify the $A$. invadans DNA from the fish samples taken from these two groups. Negative control fish did not show any illness throughout the experiment.

\section{Histological investigation}

GMS-stained muscle sections of the fish from positive control group sampled at $7 \mathrm{dpi}$ showed the presence of oomycete hyphae embedded into the fish musculature, with muscle tissues appearing necrotic around the hyphae in positive control group sampled at $7 \mathrm{dpi}$ (Fig. 6a, b). No such fungal structure was found in the RNP-2-treated (Fig. 6c, d) or negative control groups (Fig. 6e, f). Sections of the fish muscles stained with H\&E showed infiltration of macrophages and other inflammatory cells at the site of infection in positive control group (Fig. 7a, b). No such infiltration or necrosis of muscle tissues was found in the RNP-2-treated (Fig. 7c, d) or negative control groups (Fig. 7e, f).

\section{Discussion}

Production of extracellular proteins from A. invadans has been reported by Majeed et al. [20]. These proteins mainly consist of proteases that are believed to be the major virulence factors that contribute to EUS infection. One of the identified proteins contains the peptidase_S8 domain which is a subtilisin or subtilase family, the second-largest family of serine proteases. Serine proteases are present in every life form including viruses and play major roles in protein metabolism, digestion, development, host invasion and immune evasion [54]. These proteases have been reported to be the virulence factors in different pathogenic species including fungi [55-57], parasites [58, 59] and bacteria [60-62]. Accordingly, in this study, this gene was selected for gene editing using CRISPR/Cas9 system in a trial to investigate its role in EUS. Currently, ZFNs and TALENs are used for genome editing experiments but the focus has been shifted to CRISPR/Cas system for such purposes. In the present study, the phenotype of germinating $A$. invadans protoplasts treated with three different RNP complexes demonstrated a different growth patterns. The PEG-mediated RNP delivery system is the most widely used system for delivering the gRNA and Cas9 into the protoplasts of oomycete and fungi. Based on fluorescence microscopy, the transfection resulted in bright and strong fluorescence signal which confirmed the efficiency of the transfection (Fig. 1). Nevertheless, obtained

Table 2 Guide RNAs used in this study. The Eukaryotic Pathogen CRISPR Guide RNA Design Tool was used to design the gRNAs for serine type protease of $A$. invadans (gene ID: 20088162). Based on their high total and efficiency scores and zero off-target hits, three gRNAs were selected for genome modification experiment

\begin{tabular}{|c|c|c|c|c|c|}
\hline gRNA id & gRNA sequence (PAM "NGG") & $\begin{array}{l}\text { Total } \\
\text { score }\end{array}$ & $\begin{array}{l}\text { Efficiency } \\
\text { score }\end{array}$ & $\begin{array}{l}\text { On-target hits in the genome (perfect-match } \\
\text { | non-perfect-but-PAM-match) }\end{array}$ & $\begin{array}{l}\text { Off-target hits (perfect-match } \\
\text { | nonperfect-match) }\end{array}$ \\
\hline $\begin{array}{l}\text { 1. Aphanomyces- } \\
\text { invadans_106 }\end{array}$ & $\begin{array}{l}\text { GCT TAC CAG ATG GAA TGA } \\
\text { CG | TGG }\end{array}$ & 0.69 & 0.65 & $2 \mid 0$ & $0 \mid 0$ \\
\hline $\begin{array}{l}\text { 2. Aphanomyces- } \\
\text { invadans_923 }\end{array}$ & $\begin{array}{l}\text { GTG TAG CCC CAG AAG CCC } \\
\text { AA | TGG }\end{array}$ & 0.56 & 0.57 & $1 \mid 1$ & $0 \mid 0$ \\
\hline $\begin{array}{l}\text { 3. Aphanomyces- } \\
\text { invadans_1730 }\end{array}$ & $\begin{array}{l}\text { GAT GGA ACC CAA CAA CTG } \\
\text { TG | TGG }\end{array}$ & 0.53 & 0.65 & $1 \mid 0$ & $0 \mid 0$ \\
\hline
\end{tabular}




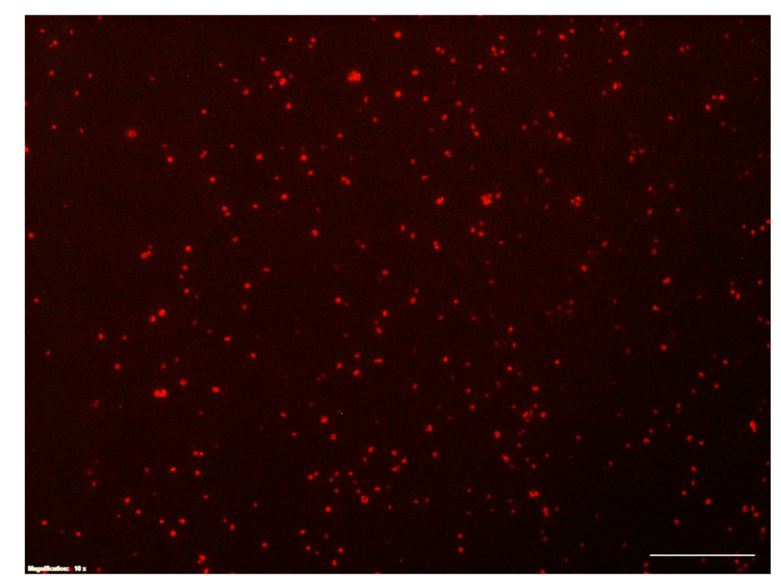

Fig. 1 Fluorescence microscope image of the protoplasts of Aphanomyces invadans. Protoplasts were transfected with RNPs carrying $A T T O^{T M}$ 550. Successful transfection shows clear RNPcomplex signals within the protoplasts after overnight incubation. Scale-bar: $100 \mu \mathrm{m}$

populations are expected to carry a mixture of mutated and non-mutated protease genes.

Sequence analysis of DNA of these protoplasts revealed the presence of point mutation in amplified fragments of the target gene caused by only one out of the selected three gRNAs. The same mutation was also detected in the zoospores treated with the same RNP complex (Fig. 4). These results confirm that only RNP- 2 caused the mutation, while the RNP-1 and RNP-3 failed to perform similarly. The failure of the RNP-1 and RNP-3 to cause mutation may be attributed to the self-complementarity which likely hindered

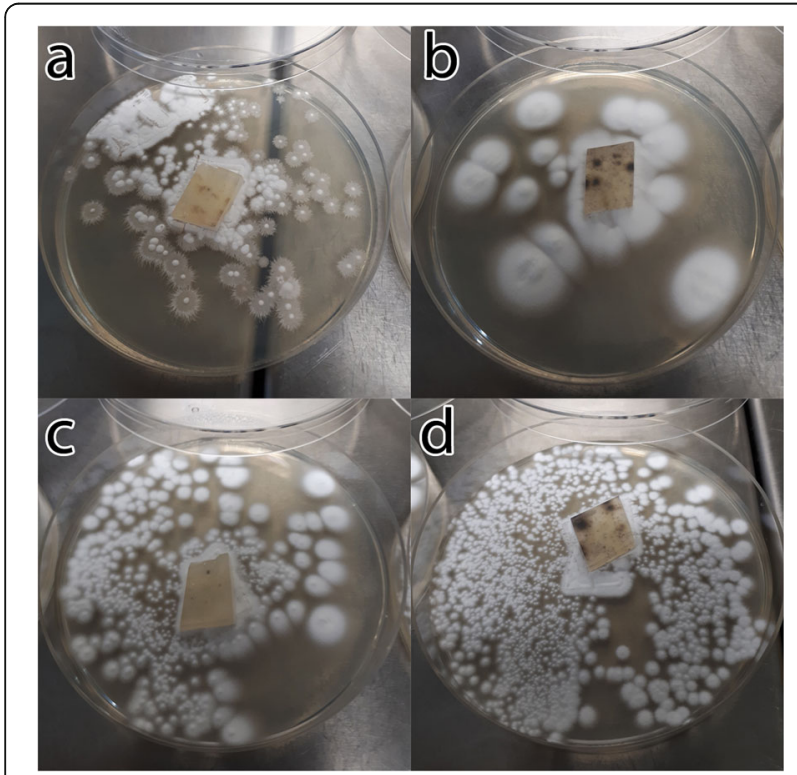

Fig. 2 Growth of RNP-transfected Aphanomyces invadans protoplasts after being transfected with RNP-1 (a), RNP-2 (b) and RNP-3 (c). d Growth of non-treated control protoplasts

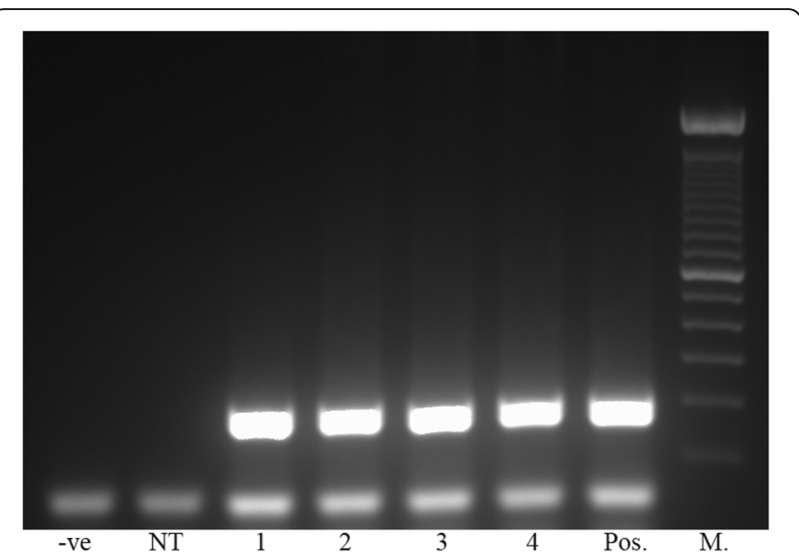

Fig. 3 PCR result (214 bp) of RNP-2-treated and non-treated protoplasts and zoospores using primer set 2. Lane -ve: negative extraction; Lane NT: non-template; Lane 1: protoplasts transfected with RNP-2; Lane 2: non-treated protoplasts; Lane 3: zoospores transfected with RNP-2. Lane 4: non-treated zoospores. Lane Pos. positive control. Lane M: marker (100 bp)

their binding to the target DNA sequence and affected their functionality [47]. The different growth pattern was only observed in the protoplasts that were treated with RNP-2 while the control and RNP-1- and RNP-3-treated protoplasts demonstrated a conventional growth pattern (Fig. 2). Furthermore, the observed slow growth pattern of the treated zoospores was likely because of the point mutation in the target gene. This indicates that the target gene may also play an important role in the growth of the A. invadans. This is supported by the fact that the target gene is a serine protease and serine proteases play major roles in regulation of development and host invasion [54]. Thus, any effective mutation in these genes will likely affect other cellular functions as well.

It seems that the target gene likely plays an important role in the virulence of the A. invadans. Dwarf guorami that were inoculated with non-treated zoospores demonstrated characteristic EUS clinical signs such as reddening, swelling, deep ulcers in skin and muscles, and visible fungal growth at the site of infection (Fig. 5a, b). On the other hand, fish that were inoculated with the RNP-2-treated zoospores did not demonstrate any clinical signs during the 30 days of the in vivo experiment (Fig. 5c). Mutation was confirmed via sequencing and all sequenced samples have this mutation. It was, however, confirmed by the in vivo experiments when the edited zoospores did not produce the EUS clinical signs. This shows that the zoospores carry the mutation.

GMS staining is the standard approach for the visualization of fungal agents in granulomatous inflammation [63, 64]. It stains the walls of the fungus and gives them dark/black coloration [53, 63]. GMS-stained histopathological sections of muscle tissues of the positive control fish at $7 \mathrm{dpi}$ clearly showed the stained 
ATGGTCCGCATTGCCTCCATCGCATCCCTCGCCGCGTCGGCCACCGCGACCATTTCCCAGCGTACCCTTCGCG

CACTCGAAACGCAAAAGGCCATCGATATCTTGGTCACCTACAAGGCCGGCCCTGGCCTCACCAAGCTCAATA CCGAGTCGTTGTCGCGTGAAGCCCGCGCCCAAGAAGTGTTCAACATCTTGACGACTGAAAACTTCGCCATCAC CGCGTCCGCCGTGGAAGTCGCCAAAGCTGCCGGAGTGAAGTACACGCAGTACTGGATCGACTCCGTTGTCGC GATTGAAGGTGCCAACGCGGAGCTCGTCGCCAAGTTGGATGCCCTTCCCAACGTCGTCAGAGTCGCCCAAGT GGAAGTGTACGAGTTGCCGGCCTTCCTCGAATCCAACCTCGTCGCGGCCAACTCCACCAACGAATGGGGTGTT GAGATGATCAGCGCCCCAGTTGCCTGGGCCCGCGGCAACAAGGGCAAGGGCATCGTCGTGGCCAATATCGAC ACCGGTGTGCGCGGCACGCATGAAGCGCTCAAGGGCAACTTCCGCGCTCAGAATGGCTGGTACGAACCCTCC Forward primer 2 ACGAAGTCCCCTGCCCCCAACGATCGACACGGCCACGGTACCCACACCATGGGAACGATTGCCGGTGCCAACG gRNA PAM
GCATCGGTGTAGCCCCAGAAGCCCAATGGATTGCGTGTGTCGGGTGCCCGGCCGGGTCATGTCCCCAAACCGA

TTTATTGGCATGCGCCCAATTCATCCTATGCCCAACCGACACGAACGGCCAGAACCCCAACTGCAAGATGGC Reverse primer 2 CCCTAGTGTCGTTAACAACTCGTGGGGCTCGTCTCAAAGCGGCAGCACGTGGTATGAAGCATCGATCCTTGCC TGGCGCAAGGCCGGCATCGTTCCCGTGTTTTCGAACGGGAACTCCGGCCCCAGCTGCGGCACCGTAGGCTCCC CTGGTGACTCCCCCTCGGTCATTGCTGTCGGTGCTACTGATATGACTGATGCATTGGCCAGCTTCAGCTCGAA AGGTCCTGAGCCCCTACAAAAGCGCATCAAGCCTGATGTGTCGGCCCCCGGTAAGGGCATTCGCTCCGCTGG TTATGCCGGCGATAGCTCGTACGTCTCGATGTCTGGTACGTCTATGGCCGCCCCCCACACCACCGGCACCGTC GCGTTGATGTTAAATGCCAACCCCGGTGCCACCTATGAAACCGTGTACAAGTTGATCACCGGTTCGGTCGATA CGGCCACGTTGAAGCCATCCACTGCCAACTGCGGTGGTGTGGACAACTCCAAGTACCCCAACAACGACTTCG GGTTCGGCCGTATTAACGCCAACAAGGCGTCCGCCTCGGGTTCGTCCACCCCCGCTCCTACCTCCGCCAATCC CGCGTGCTAA

Fig. 4 Coding sequence (mRNA sequence) of Aphanomyces invadans' hypothetical protein (GenBank: XM_008877667) contains 1388 nucleotides. The designed gRNA2 site is highlighted in green and the PAM site in grey. Forward and reverse primer 2 (product size 214 bp) sites are highlighted in yellow. The point mutation (deletion) located at the 5 th $\mathrm{nt}$ from the PAM site is shown in red within the gRNA2 sequence

oomycete hyphae (Fig. 6a, b). Necrosis of muscle tissues were observed around the area of the hyphae, likely because of the intense inflammatory response [65]. Accumulation of macrophages and other inflammatory cells at the site of infection were also observed in $\mathrm{H} \& \mathrm{E}$ stained sections (Fig. 7a, b). Presence of $A$. invadans hyphae in fish musculature during EUS infection has been reported [14,65] and our findings are in accordance with these results. Muscle sections of RNP-2-treated and negative control fish did not show any hyphae in GMS

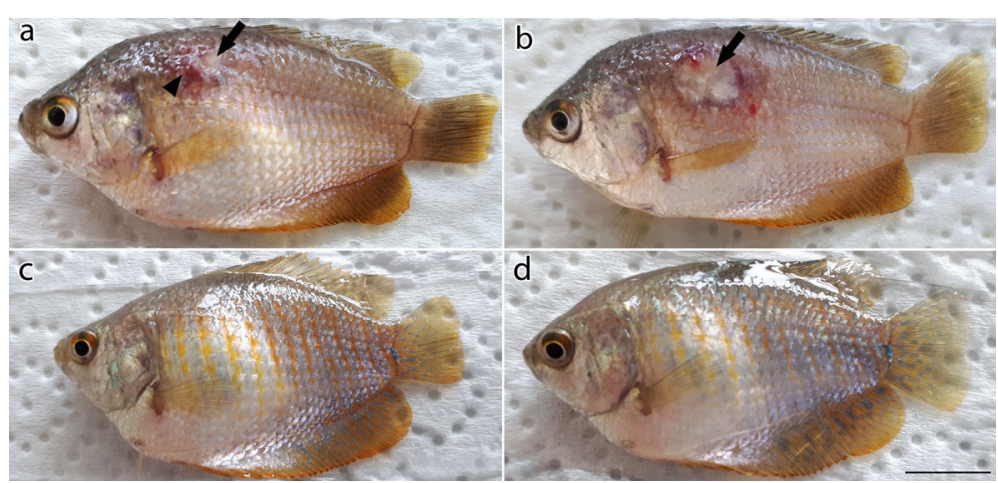

Fig. 5 Dwarf gourami showing necrotic ulceration after infection with the zoospores of $A$. invadans. Zoospore suspension (0.1 ml) coniatining 10,000 zoospores $/ \mathrm{ml}$ of $A$. invadans was injected intramuscularly. a Positive control fish showing the reddening of the infected area (arrowhead) and the beginning of ulcer formation (arrow) at the site of infection at 3 dpi. b Positive control fish showing clear oomycete growth and necrotic ulceration (arrow) at the site of infection at 7 dpi. c Fish injected with RNP-2-treated A. invadans zoospores showing no clinical signs at 7 dpi. $\mathbf{d}$ Negative control fish at 7 dpi. Scale-bar: $1 \mathrm{~cm}$ 


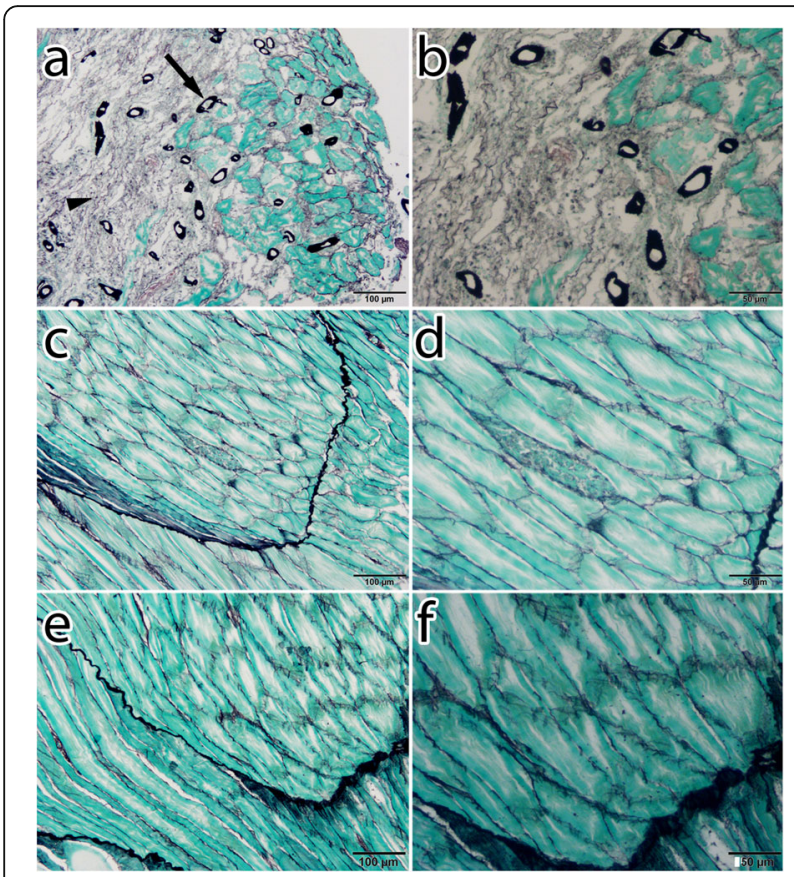

Fig. 6 Gomori's methenamine silver-stained muscle sections of dwarf gourami. a Muscle section of positive control fish showing presence of A. invadans as a black hollow structure (arrow) and muscle necrosis (arrowhead) in the gray area. $\mathbf{b}$ Higher magnification of $\mathbf{a}$. c Muscle section of the fish inoculated with RNP-2-treated zoospores showing intact muscle with no oomycete hyphae. $\mathbf{d}$ Higher magnification of $\mathbf{c}$ e Muscle section of negative control fish showing intact muscle with no oomycete hyphae. $\mathbf{f}$ Higher magnification of e. Scale-bars: $\mathbf{a}, \mathbf{c}, \mathbf{e}$ $100 \mu \mathrm{m} ; \mathbf{b}, \mathbf{d}, \mathbf{f}, 50 \mu \mathrm{m}$

staining and no infiltration of inflammatory cells was seen in H\&E stained sections of these fish at $7 \mathrm{dpi}$.

During CRISPR/Cas9-mediated genome editing, the suppression of the target gene by gRNA-complex appearently affects oomycete development and virulence, resulting in the cessation of $A$. invadans pathogenesis. The results obtained from this study hint on the fact that the serine proteases are definitely required by the oomycete in order to invade the fish and penetrate into the muscles. Protease production was likely affected in RNP-2-treated A. invadans, which might have hindered the production of other essential proteins as well. Thus, the oomycete was left unable to invade the fish musculature.

\section{Conclusions}

In this study, despite lacking prerequisite information on molecular mechanisms of pathogenicity and interactions of $A$. invadans with the fish host, the CRISPR/Cas9 system was successfully applied to edit the serine protease gene of $A$. invadans. Our study establishes that CRISPR/ Cas9 is a promising tool and offers a great opportunity to plan more advanced genomic studies on oomycetes to understand the role of different secreted proteases, their virulence mechanisms, and their interactions with their

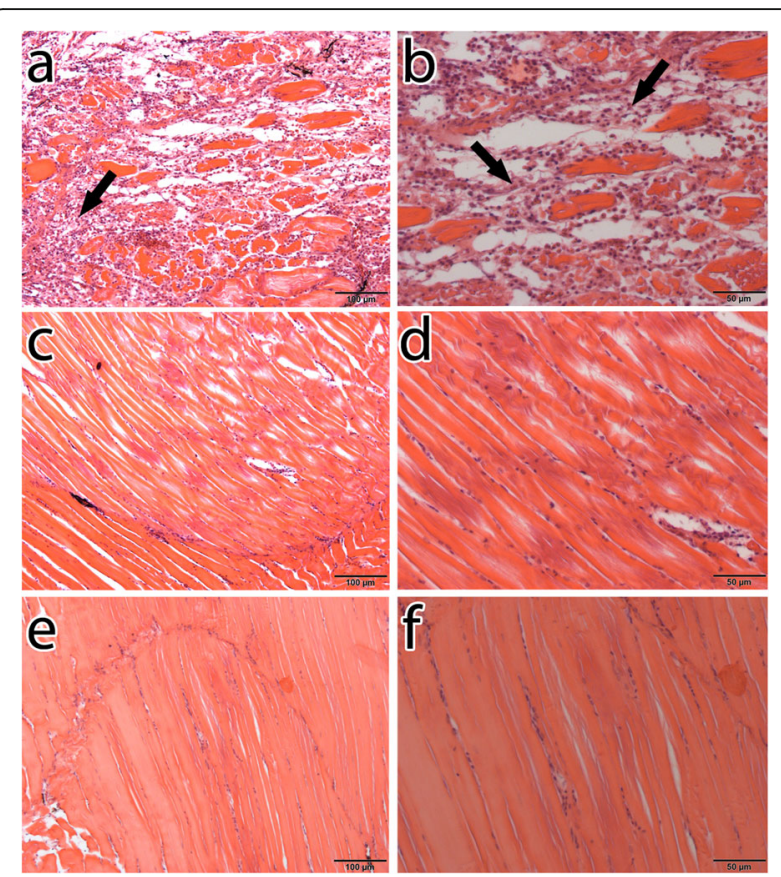

Fig. 7 Hematoxylin and eosin-stained muscle sections of dwarf gourami. a Muscle section of positive control fish showing muscle necrosis (arrow). b Muscle section of positive control fish showing high infiltration of macrophages and other inflammatory cells (arrows). c Muscle section of the fish inoculated with RNP-2-treated zoospores showing no necrosis or infiltration of macrophages. $\mathbf{d}$ Higher magnification of $\mathbf{c}$. e Muscle section of negative control fish showing no necrosis or infiltration of macrophages. $\mathbf{f}$ Higher magnification of e. Scale-bars: a, c, e, $100 \mu \mathrm{m} ; \mathbf{b}, \mathbf{d}, \mathbf{f}, 50 \mu \mathrm{m}$

hosts. In addition, our study provides a basis for further investigations of molecular mechanisms previously suggested to be involved in EUS and may help the development of novel drugs and control methods to combat their deleterious effects in fish.

\section{Abbreviations}

APW: Autoclaved pond water; Cas9: CRISPR-associated protein 9; CRISPR: Clustered regularly interspaced short palindromic repeats; CrRNA: CRISPR RNA; dpi: Days post-infection; EuPaGDT: Eukaryotic Pathogen CRISPR Guide RNA Design Tool; EUS: Epizootic ulcerative syndrome; GMS: Grocott's methenamine silver nitrate stain; GP: Glucose peptone; GPY: Glucose peptone yeast; gRNA: Guide RNA; H\&E: Hematoxylin and eosin; MES: 2-(N-morpholino)ethanesulfonic acid; PEG: Polyethylene glycol; RNP: Ribo-nucleo-protein; RT: Room temperature; TALEN: Transcription activator-like effector nuclease(s); ZFN: Zinc finger nuclease(s)

\section{Acknowledgements}

MM thanks the Higher Education Commission of Pakistan for providing the scholarship to study abroad and Österreichische Austauschdienst for their institutional support and guidance.

\section{Funding}

This study was funded by the University of Veterinary Medicine, Vienna (PP291-ELM), and the Austrian Science Fund (FWF) Project No. P29294-B25.

\section{Availability of data and materials}

All data supporting the conclusions of this article are presented within the article. 


\section{Authors' contributions}

MEM and MS conceived the study. MM and HS performed the experiments. MM, HS, GK and MS were involved in data acquisition and analyses. MM wrote the manuscript and HS, GK, MEM and MS revised it. All authors read and approved the final manuscript.

\section{Ethics approval and consent to participate}

This study was approved by the animal experimentation ethics committee of the University of Veterinary Medicine, Vienna, Austria, and by the Ministry of Science, Austria, according to paragraph 26 of the Austrian Law for Animal Experiments under the number GZ-68.205/0014-WFN/3b/2017.

\section{Consent for publication}

Not applicable.

\section{Competing interests}

The authors declare that they have no competing interests.

\section{Publisher's Note}

Springer Nature remains neutral with regard to jurisdictional claims in published maps and institutional affiliations.

\section{Received: 11 July 2018 Accepted: 3 October 2018}

\section{Published online: 23 October 2018}

\section{References}

1. Carris LM, Little CR, Stiles CM. Introduction to Fungi. The Plant Health Instructor. 2018. http://www.apsnet.org/edcenter/intropp/PathogenGroups/ Pages/IntroFungi.aspx. Accessed 04 Jul 2018.

2. Willoughby LG, Pickering AD. Viable Saprolegniaceae spores on the epidermis of the salmonid fish Salmo trutta and Salvelinus alpinus. Trans $\mathrm{Br}$ Mycol Soc. 1977;68:91-5.

3. Blazer VS, Wolke RE. An exopholia-like fungus as the cause of a systematic mycosis of marine fish. J Fish Dis. 1979;2:145-52

4. Gozlan RE, Marshall WL, Lilje O, Jessop CN, Gleason FH, Andreou D. Current ecological understanding of fungal-like pathogens of fish: what lies beneath? Front Microbiol. 2014;5:1-16.

5. Scott WW. A monograph of the genus Aphanomyces. Virginia Agr Exp Sta Tech Bull. 1961;151:1-95.

6. Diéguez-Uribeondo J, García MA, Cerenius L, Kozubíková E, Ballesteros I, Windels C, et al. Phylogenetic relationships among plant and animal parasites, and saprotrophs in Aphanomyces (Oomycetes). Fungal Genet Biol. 2009;46:365-76.

7. Roberts RJ, Willoughby LG, Chinabut S. Mycotic aspects of epizootic ulcerative syndrome (EUS) of Asian fishes. J Fish Dis. 1993;16:169-83.

8. Blazer VS, Vogelbein WK, Densmore CL, May EB, Lilley JH, Zwerner DE. Aphanomyces as a cause of ulcerative skin lesions of menhaden from Chesapeake Bay tributaries. J Aquat Anim Health. 1999;11:340-9.

9. Lilley JH, Callinan RB, Chinabut S, Kanchanakhan S, MacRae RH, Phillips MJ. Epizootic ulcerative syndrome (EUS) technical handbook. Bangkok: Aquatic Animal Health Research Institute; 1998.

10. Kiryu Y, Shields JD, Vogelbein WK, Kator H, Blazer VS. Infectivity and pathogenicity of the oomycete Aphanomyces invadans in Atlantic menhaden Brevoortia tyrannus. Dis Aquat Org. 2003;54:135-46.

11. Willoughby LG, Roberts RJ, Chinabut S. Aphanomyces invaderis sp. nov., the fungal pathogen of freshwater tropical fishes affected by epizootic ulcerative syndrome (EUS). J Fish Dis. 1995;18:273-5.

12. Oidtmann B. Review of biological factors relevant to import risk assessments for epizootic ulcerative syndrome (Aphanomyces invadans). Transbound Emerg Dis. 2012;59:26-39.

13. Pathiratne A, Widanapathirana GS, Chandrakanthi WHS. Association of Aeromonas hydrophila with epizootic ulcerative syndrome (EUS) of freshwater fish in Sri Lanka. J Appl Ichthyol. 1994;10:204-8.

14. Lilley JH, Roberts RJ. Pathogenicity and culture studies comparing the Aphanomyces involved in epizootic ulcerative syndrome (EUS) with other similar fungi. J Fish Dis. 1997;20:135-44.

15. Vishwanath TS, Mohan CV, Shankar KM. Epizootic Ulcerative Syndrome (EUS), associated with a fungal pathogen, in Indian fishes: histopathology 'a cause for invasiveness'. Aquaculture. 1998;165:1-9.

16. Kamilya D, Baruah A. Epizootic ulcerative syndrome (EUS) in fish: history and current status of understanding. Rev Fish Biol Fish. 2014;24:369-80.
17. OIE. OIE-listed diseases, infections and infestations. 2018. http://www.oie.int/en/ animal-health-in-the-world/oie-listed-diseases-2018/. Accessed 10 Jul 2018.

18. OIE. Infection with Aphanomyces invadans (epizootic ulcerative syndrome) In: Manual of diagnostic tests for aquatic animals. World Organisation for Animal Health; 2018. http://www.oie.int/standard-setting/aquatic-manual/ access-online/. Accessed 10 Jul 2018.

19. Yadav MK, Pradhan PK, Sood N, Chaudhary DK, Verma DK, Debnath C, et al. Innate immune response of Indian major carp, Labeo rohita infected with oomycete pathogen Aphanomyces invadans. Fish Shellfish Immunol. 2014; 39:524-31.

20. Majeed M, Kumar G, Schlosser S, El-Matbouli M, Saleh M. In vitro investigations on extracellular proteins secreted by Aphanomyces invadans, the causative agent of epizootic ulcerative syndrome. Acta Vet Scand. 2017;59:78.

21. Minor KL, Anderson VL, Davis KS, van den Berg AH, Christie JS, Lobach L, et al. A putative serine protease, SpSsp1, from Saprolegnia parasitica is recognised by sera of rainbow trout, Oncorhynchus mykiss. Fungal Biol. 2014;118:630-9.

22. Jiang RHY, de Bruijn I, Haas BJ, Belmonte R, Lobach L, Christie J, et al. Distinctive expansion of potential virulence genes in the genome of the oomycete fish pathogen Saprolegnia parasitica. PLoS Genet. 2013;9: e1003272.

23. Gaj T, Gersbach CA, Barbas CF 3rd. ZFN, TALEN, and CRISPR/Cas-based methods for genome engineering. Trends Biotechnol. 2013;3:397-405.

24. Urnov FD, Rebar EJ, Holmes MC, Zhang HS, Gregory PD. Genome editing with engineered zinc finger nucleases. Nat Rev Genet. 2010;11:636-46.

25. Carroll D. Genome engineering with zinc-finger nucleases. Genetics. 2011; 188:773-82.

26. Sun N, Zhao H. Transcription activator-like effector nucleases (TALENs): A highly efficient and versatile tool for genome editing. Biotechnol Bioeng. 2013;110:1811-21.

27. Doudna JA, editing CEG. The new frontier of genome engineering with CRISPR-Cas9. Science. 2014;346:1258096

28. Barrangou R. The roles of CRISPR-Cas systems in adaptive immunity and beyond. Curr Opin Immunol. 2015;32:36-41.

29. Wright AV, Nuñez JK, Doudna JA. Biology and applications of CRISPR Systems: harnessing nature's toolbox for genome engineering. Cell. 2016;164:29-44.

30. Garneau JE, Dupuis ME, Villion M, Romero DA, Barrangou R, Boyaval P, et al. The CRISPR/Cas bacterial immune system cleaves bacteriophage and plasmid DNA. Nature. 2010:468:67-71.

31. Gasiunas G, Barrangou R, Horvath P, Siksnys V. Cas9-crRNA ribonucleoprotein complex mediates specific DNA cleavage for adaptive immunity in bacteria. Proc Natl Acad Sci USA. 2012;109:E2579-86.

32. Jinek M, Chylinski K, Fonfara I, Hauer M, Doudna JA, Charpentier E. A programmable dual-RNA-guided DNA endonuclease in adaptive bacterial immunity. Science. 2012;337:816-21.

33. Rath $D$, Amlinger $L$, Rath $A$, Lundgren $M$. The CRISPR-Cas immune system: Biology, mechanisms and applications. Biochimie. 2015;117:119-28.

34. Jiang F, Doudna JA. CRISPR-Cas9 Structures and Mechanisms. Annu Rev Biophys. 2017:46:505-29.

35. Pellagatti A, Dolatshad H, Valletta S, Boultwood J. Application of CRISPR/ Cas9 genome editing to the study and treatment of disease. Arch Toxicol. 2015:89:1023-34.

36. Oishi I, Yoshii K, Miyahara D, Kagami H, Tagami T. Targeted mutagenesis in chicken using CRISPR/Cas9 system. Sci Rep. 2016;6:23980.

37. Wang X, Cai B, Zhou J, Zhu H, Niu Y, Ma B, et al. Disruption of FGF5 in Cashmere goats using CRISPR/Cas9 results in more secondary hair follicles and longer fibers. PLoS One. 2016;11:e0164640.

38. Wu M, Wei C, Lian Z, Liu R, Zhu C, Wang H, Cao J, et al. Rosa26-targeted sheep gene knock-in via CRISPR-Cas9 system. Sci Rep. 2016;6:24360.

39. Liu Q, Gao R, Li J, Lin L, Zhao J, Sun W, et al. Development of a genomeediting CRISPR/Cas9 system in thermophilic fungal Myceliophthora species and its application to hyper-cellulase production strain engineering. Biotechnol Biofuels. 2017;10:1.

40. Pohl C, Kiel JA, Driessen AJ, Bovenberg RA, Nygård Y. CRISPR/Cas9 based genome editing of Penicillium chrysogenum. ACS Synth Biol. 2016;5:754-64.

41. Katayama T, Tanaka Y, Okabe T, Nakamura H, Fujii W, Kitamoto K, et al. Development of a genome editing technique using the CRISPR/Cas9 system in the industrial filamentous fungus Aspergillus oryzae. Biotechnol Lett. 2016:38:637-42.

42. Zhang H, Cheng QX, Liu AM, Zhao GP, Wang J. A novel and efficient method for bacteria genome editing employing both CRISPR/Cas9 and an antibiotic resistance cassette. Front Microbiol. 2017;8:812. 
43. Altenbuchner J. Editing of the Bacillus subtilis genome by the CRISPR-Cas9 system. Appl Environ Microbiol. 2016;82:5421-7.

44. Wang Y, Zhang ZT, Seo SO, Lynn P, Lu T, Jin YS, et al. Bacterial genome editing with CRISPR-Cas9: deletion, integration, single nucleotide modification, and desirable "clean" mutant selection in Clostridium beijerinckii as an example. ACS Synth Biol. 2016;5:721-32.

45. Jiang W, Bikard D, Cox D, Zhang F, Marraffini LA. RNA-guided editing of bacterial genomes using CRISPR-Cas systems. Nat Biotechnol. 2013;31:233-9.

46. Tyler BM. Phytophthora sojae: root rot pathogen of soybean and model oomycete. Mol Plant Pathol. 2007:8:1-8.

47. Fang Y, Cui L, Gu B, Arredondo F, Tyler BM. Efficient genome editing in the oomycete Phytophthora sojae using CRISPR/Cas9. Curr Protoc Microbiol. 2017:44:21A 1.1-21A.1.26

48. Fang Y, Tyler BM. Efficient disruption and replacement of an effector gene in the oomycete Phytophthora sojae using CRISPR/Cas9. Mol Plant Pathol. 2016;17:127-39.

49. Peng D, Tarleton R. EuPaGDT: a web tool tailored to design CRISPR guide RNAs for eukaryotic pathogens. Microb Genom. 2015;1:e000033.

50. Bellaousov S, Reuter JS, Seetin MG, Mathews DH. RNAstructure: Web Servers for RNA secondary structure prediction and analysis. Nucleic Acids Res. 2013;41:W471-4.

51. Malnoy M, Viola R, Jung MH, Koo OJ, Kim S, Kim JS, et al. DNA-free genetically edited grapevine and apple protoplast using CRISPR/Cas9 ribonucleoproteins. Front Plant Sci. 2016;7:1904.

52. Vandersea MW, Litaker RW, Yonnish B, Sosa E, Landsberg JH, Pullinger C, et al. Molecular assays for detecting Aphanomyces invadans in ulcerative mycotic fish lesions. Appl Environ Microbiol. 2006;72:1551-7.

53. Haque A. Special stains use in fungal infections. In: Kumar GL, Kiernan JA, editors. Special Stains and H \& E. 2nd Ed. California: Dako; 2010. p. 230-40.

54. Di Cera E. Serine proteases. IUBMB Life. 2009;61:510-5.

55. Pannkuk EL, Risch TS, Savary BJ. Isolation and identification of an extracellular subtilisin-like serine protease secreted by the bat pathogen Pseudogymnoascus destructans. PLoS One. 2015;10:e0120508.

56. Valueva TA, Kudryavtseva NN, Sofyin AV, Zaitchik BT, Pobedinskaya MA, Kokaeva LY, et al. Serine exoproteinases secreted by the pathogenic fungi of Alternaria genus. J Plant Pathol Microbiol. 2015;6:272.

57. Xu J, Baldwin D, Kindrachuk C, Hegedus DD. Serine proteases and metalloproteases associated with pathogenesis but not host specificity in the entomophthoralean fungus Zoophthora radicans. Can J Microbiol. 2006;52:550-9.

58. Yang Y, Wen YJ, Cai YN, Vallée I, Boireau P, Liu MY, et al. Serine proteases of parasitic helminths. Korean J Parasitol. 2015;53:1-11.

59. Toubarro D, Lucena-Robles M, Nascimento G, Santos R, Montiel R, Veríssimo $P$, et al. Serine protease-mediated host invasion by the parasitic nematode Steinernema carpocapsae. J Biol Chem. 2010;285:30666-75.

60. Wessler S, Schneider G, Backert S. Bacterial serine protease HtrA as a promising new target for antimicrobial therapy? Cell Commun Signal. 2017;15:4.

61. Ruiz-Perez F, Nataro JP. Bacterial serine proteases secreted by the autotransporter pathway: classification, specificity, and role in virulence. Cell Mol Life Sci. 2014;71:745-70.

62. Nissinen R, Xia Y, Mattinen L, Ishimaru CA, Knudson DL, Knudson SE, et al. The putative secreted serine protease Chp-7 is required for full virulence and induction of a nonhost hypersensitive response by Clavibacter michiganensis subsp. sepedonicus. Mol Plant Microbe Interact. 2009;22:809-19.

63. Guo C, Ghadersohi S, Kephart GM, Laine RA, Sherris DA, Kita H, et al. Improving the detection of fungi in eosinophilic mucin: seeing what we could not see before. Otolaryngol Head Neck Surg. 2012;147:943-9.

64. Grocott RG. A stain for fungi in tissue sections and smears using Gomori's methenamine-silver nitrate technic. Am J Clin Pathol. 1955;25:975-9.

65. Huchzermeyer KD, van der Waal BC. Epizootic ulcerative syndrome: exotic fish disease threatens Africa's aquatic ecosystems. J S Afr Vet Assoc. 2012;83:204.

\section{Ready to submit your research? Choose BMC and benefit from:}

- fast, convenient online submission

- thorough peer review by experienced researchers in your field

- rapid publication on acceptance

- support for research data, including large and complex data types

- gold Open Access which fosters wider collaboration and increased citations

- maximum visibility for your research: over $100 \mathrm{M}$ website views per year

At BMC, research is always in progress.

Learn more biomedcentral.com/submissions 